\title{
Impact of conservational agriculture on hydrological properties of rainfed alfisol
}

\section{R. BHEEMANNA, H. V. RUDRAMURTHY, P. H. KUCHNUR AND CHANDRAGOUDAGIRIGOUDAR}

MEMBERS OF RESEARCH FORUM:

Corresponding author : H.V. RUDRAMURTHY, College of Agriculture (U.A.S.), BHEEMARAYANAGUDI (KARNATAKA) INDIA

Email: drrmurthy@gmail.com

Co-authors :

R. BHEEMANNA, P.H.

KUCHNUR AND

CHANDRAGOUDA

GIRIGOUDAR, College

of Agriculture (U.A.S.),

BHEEMARAYANAGUDI (KARNATAKA)

INDIA

Received : 17.02.2017; Revised : 27.04.2017; Accepted : 10.05.2017

\section{Summary}

Retention and movement of water was better in conservational agricultural systems as compared to conventional agricultural system. Statistical tool Tukey test suggested that conservational agricultural systems that too raised bed with retention of crop residue at soil surface recorded statistically significant available water, water held at field capacity and permanent wilting point over that of conventional agricultural system and however, another statistical tool Pearson correlation indicated that neither tillage, crop residue retention at surface nor raised bed influenced water retention characteristics of soil such as MWHC, AW, water at FC and PWP which were significantly correlated with particle size class rather than organic carbon the resultant product of management factors. Other hydrological properties of soil such as infiltration rate, water storage capacity as well as hydraulic conductivity were better in conservational agricultural systems than in conventional agricultural system and however, infiltration rate and hydraulic conductivity were significantly superior in no tilled soil with raised bed and crop residue retained at soil surface.

Key words : Available water, Infiltration rate, Hydraulic conductivity, Reduced tillage, Crop residue retention

How to cite this article : Bheemanna, R., Rudramurthy, H.V., Kuchnur, P.H. and Girigoudar, Chandragouda (2017). Impact of conservational agriculture on hydrological properties of rainfed alfisol. Asian J. Soil Sci., 12 (1) : 128-134 : DOI : 10.15740/HAS/AJSS/12.1/128-134. 